\title{
The Use of Wondershare Filmora Version 7.8.9 Media Apps in Flipped Classroom Teaching
}

\author{
Cahyo Hasanudin ${ }^{*}$, Ayu Fitrianingsih ${ }^{2}$, Kundharu Saddhono $^{3}$ \\ ${ }^{1}$ Indonesian Language and Literature Education Department, IKIP PGRI Bojonegoro, 62114, Indonesia \\ ${ }^{2}$ English Education Department IKIP PGRI Bojonegoro, 62114, Indonesia \\ ${ }^{3}$ Graduate School of Universitas Sebelas Maret Surakarta, 57126, Indonesia
}

Corresponding Author Email: cahyo.hasanudin@ikippgribojonegoro.ac.id

https://doi.org/10.18280/rces.060301

Received: 3 May 2019

Accepted: 20 August 2019

\section{Keywords:}

Wondershare Filmora Version 7.8.9, Indonesian language, 2013 curriculum, flipped classroom, teaching material

\begin{abstract}
The purpose of this study is to investigate the concept of flipped classroom method in the teaching of Indonesian language 2013 curriculum using wondershare filmora version 7.8.9 media apps. The theory of Kuhlthau was established in this study that used six stages of composing, namely 1) choosing the topic, 2) exploring the informations, 3) determining the focus of the research, 4) preparing the data source, 5) preparing the data presentation, and 6) compiling the report. The sources of data are obtained from national and international journals, Indonesian and foreign textbooks. Through this study, it was found that there are seven stages in implementing flipped classroom method. The results indicate that those stages are adjusted to 2013 curriculum to produce the syntax of flipped classroom method using scientific approach. The findings of this study may serve as the innovation in teaching Indonesian language by implementing wondershare filmora version 7.8.9 media apps. The teaching materials in form of videos can be easily accessed by students.
\end{abstract}

\section{INTRODUCTION}

The application of Indonesian language subject is still considered to be difficult by a number of students. It can be seen from the average score of Indonesian language is low compared to another subjects. According to the data of Ministry of Education and Culture about the high school students, their average score of Indonesian language subject in National Examination is 65.77 for science students $(I P A)$ and 57.62 for social students (IPS) [1]. The results of research by Basuki, Suryani, and Setiyadi [2] show that students have difficulties in the field of language, i.e., $61.07 \%$ about the structure and $52.6 \%$ about the vocabulary. In the field of language skills, students have difficulties in $41.88 \%$ of listening, $18.89 \%$ of speaking, $21.15 \%$ of reading, and $20.02 \%$ of writing. In the field of literature, students have difficulties in $45.69 \%$ of literary knowledge, $40.9 \%$ of concepts, $41.74 \%$ of perspective, and $47.1 \%$ of literary appreciation. Based on this condition, Muslimin says [3] that the effort to improve the quality of Indonesian language teaching is by implementing Information Communication Technology (ICT) School Models.

Indonesian language is compulsory subject in every level of education. At the elementary to high school, it has been listed in 2013 curriculum, while in the university, it is in form of General Basic Course (GBC) under the auspices of The Belmawa Directorate General of Kemenristekdikti. According to Suherli [4] the Indonesian language subject aims to make students to be able to listen, read, view, speak and write. Based on Permendiknas [5] Indonesian language learning aims to enjoy and utilize literary works to broaden knowledge, refine characters, and improve language skills. Students are also directed to be able to appreciate and make proud of Indonesian literary works as human culture and intellectual.
Based on this goal, Indonesian language subject always contains the value of knowledge and skills of every competencies. These competencies are based on the three fields, namely, language, literature, and literacy. In the field of language, learners are expected to be able to have comprehensive knowledge about language and be able to apply it in oral and written form by paying great attention to the rules of using Indonesian language properly and correctly. In the field of literature, learners are expected to be able to understand, appreciate, respond, analyze, critisize, and create oral and written literary works. In the field of literacy, learners are expected to be able to improve their language and literary skills, and apply it in reading and writing activities on a daily life.

One of the solutions can be done in teaching Indonesian language subject is to apply the flipped classroom method using wondershare filmora version 7.8.9. Flipped Classroom is introduced for the first time by Bergman and Aaron in 2001. Many researchers had used this method in teaching process. In other words, flipped classroom means the students have to read or study first at home, teacher gives no more explanation about the teaching materials. According to Basal [6] flipped classroom is a teaching process in which students learn the materials independently, then they are able to master the previous materials. Furthermore, Herala et al. [7] think that flipped classroom is a method in which students learn the materials first outside the classroom and have a practice in class with teacher's guidance.

In the class, students have to discuss what they have read at home or they only do the assignments given at that time. Then, they apply theories to solve the problems and have a group discussion. Teacher's role is not to provide materials in the class, so he will have much more time interacting with his students. His role is as a facilitator and observer of the learning 
process. In line with Damayanti and Sutama [8], flipped classroom reverses what is generally done in class into what is done as homework. The gists of flipped classroom teaching [9] are 1) providing more time in class to assimilate materials in form of exercises, or another activities, and 2) accommodating students' differences in motivation, learning ability, and prior knowledge. Johnson [10] says that flipped classroom method is teacher's strategy to minimize the number of direct instructions and maximize the students' interactions. This strategy utilizes technology that provides additional online materials.

Based on the expert's opinions above, it is clear that flipped classroom method requires technological assistance. It can be in form of applications, videos, or internet connections. In flipped classroom method, students not only learn inside the classroom, but they can also access or learn the materials given by the teacher repeatedly using internet or learning video provided. Hasanudin and Fitrianingsih [11] added that teacher who implemented flipped classroom using Screencast-OMatic Apps contributed to the students' of Indonesian language and literature program to have better reading skill. Flipped classroom teaching requires students to learn the materials independently, it is usually assisted by providing video files made by the teacher, instructor, or collaboration between them.

Related to the use of video in flipped classroom teaching, the researchers use wondershare filmora version 7.8.9. This media application is a free player and editor of a video released by Wondershare Software (H.K.) Co., Ltd., one of the video editors that has cool features and is easy to use. It can be viewed from the way to give video transition effects and animated text, the editing process of video is fast and uncomplicated. In line with the opinion of Punusingon et al. [12] that wondershare filmora application can create, edit, cut, and convert videos. The features of this application can handle various video editing to make it valuable. This application has an icon as follow in Figure 1.

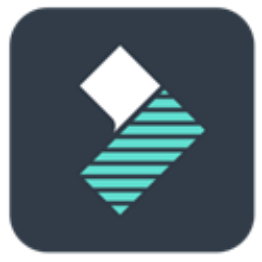

Figure 1. The icon of wondershare filmora version 7.8.9

The home page of wondershare filmora version 7.8.9. can be shown in Figure 2.

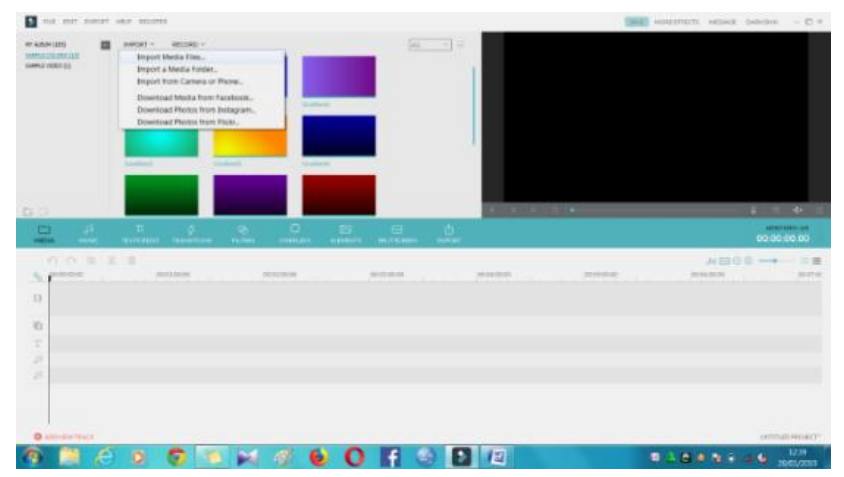

Figure 2. Home page of wondershare filmora version 7.8.9
By using this application, the researchers hope that the video is able to give a good contribution to flipped classroom teaching. The filmora application has been used [13] in adding English subtitles and adjusting music background. Negara and Jumrotin [14] use filmora application in making videos on the materials of alphabets, numbers, religions, subjects, family, time, color, fruit, directions, transportation, animals and professions. In this article, wondershare filmora version 7.8.9 is used to compile the materials of anecdote and expected to make learners become very enthusiastic and have complete learning in studying Indonesian language subject, and there is no longer assumption that Indonesian language subject is 'difficult'.

The remainder of this paper is organized as follows: Section 2 introduces about the research methodology, Section 3 describes the research findings and compares it to the relevant previous studies, and Section 4 concludes the contributions and implications of the results of study.

\section{METHODOLOGY}

This is a library research. It is a theoretical study, reference, and literature on culture and values of social situations [15] which is useful to obtain theoretical basis [16]. Library research limits its scope only in the study of references rather than on field research [17].

\subsection{Research procedures}

The procedure of library research is used to arrange the concept of flipped classroom in teaching Indonesian language subject by using wondershare filmora version 7.8.9. The steps are 1) choosing the topic, 2) exploring the informations, 3) determining the focus of the research, 4) preparing the data source, 5) preparing the data presentation, and 6) compiling the report [18].

\subsection{Data source}

The data is obtained from national and international journals, Indonesian and foreign textbooks about flipped classroom method, wondershare filmora version 7.8.9 media application, and Indonesian language learning. These references are organized based on research procedure, so it produces the concept of teaching Indonesian language subject using flipped classroom method with the media application of wondershare filmora version 7.8.9.

\section{RESULTS AND DISCUSSION}

\subsection{Results}

Based on the observations on flipped classroom teaching, the teacher applies the steps of instructions in line with Bergmann \& Sams [19] i.e., 1) the first day of flipped classroom, 2) inform the students about flipped classroom model, 3) teach students how to access the videos, 4) instruct students to build a question, 5) ask students to help each other, 6) build the assessment system, 7) students examine their understandings towards more complicated assignments. The explanations are as follows. 


\subsubsection{The first day of flipped classroom}

The teacher of Indonesian language subject arranges the materials based on the basic competence. This materials are organized in Microsoft PowerPoint, then it is produced using wondershare filmora version 7.8.9 as outlined in the following steps 1) click the icon of application, 2) choose the full feature, 3) import the media, 4) choose the place of media, 5) open, 6) click the sign ' + ', 7) set the duration, 8) add text to the media, 9) Click advance to have more editing process, 10) edit the text duration, 11) add music, 12) set the duration of music, 13) add the audio recorder, 14) add transitions of media, 15) Export the video (choose the settings and best to make video with a higher quality), 16) set the video format, file name, and place to save file, then click export as shown in Figure 3.

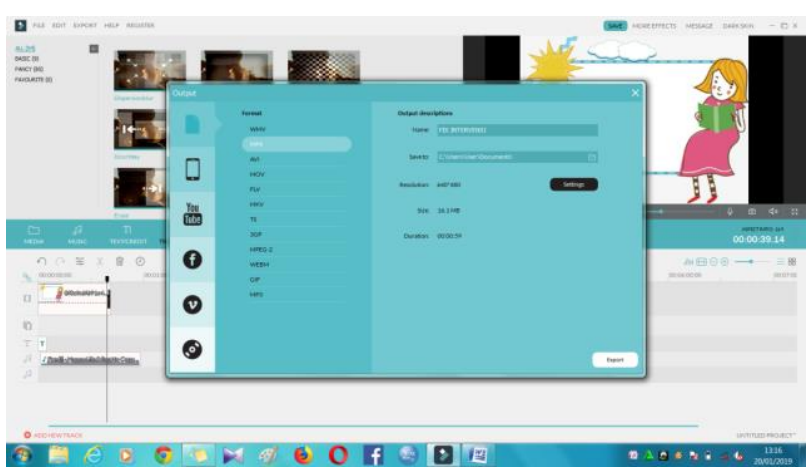

Figure 3. Set the video format, file name, and place to save file finish

17) click find target, and 18) choose the saving place and

\subsubsection{Inform the students about flipped classroom model}

In this stage, the teacher asks students to understand the concept of flipped classroom model. The students are explained about flipped classroom teaching, start from how to access the video, play the video and understand it at home, make a list of questions related to the video, the way to deliver arguments in learning, and the way to answer the questions of their classmates.

\subsubsection{Teach students how to access the videos}

The teacher asks the students through SMS, WhatsApp, publication board, or the class captain to access the video uploaded in YouTube web page https:/www.youtube.com/watch?v=cH9Q-

CePljI\&feature=youtu.be. In this stage, the teacher must control the students who cannot access it by teaching them the way to access the video. It is done to make the material is universally channeled.

\subsubsection{Instruct the students to build a question}

This step can be said as form of assimilation. The teacher instructs students to build a question related to the material that has been downloaded. He only gives instructions without giving explanation about the material. Meanwhile, the students' assignment is to study the materials at home and make a question that will be used as topic of discussion. This form of assimilation is carried out by students out of the learning hours.

\subsubsection{Ask students to help each other}

At this stage, the teacher and students are implementing flipped classroom method in the class. Students have to be able to convey questions in front of the class. Teacher provides opportunities for them to interact each other by giving questions and answers. He instructs students to master the materials. They interact each other to analyze, evaluate, and make a new concept. The important point is that students are able to think critically in solving the problems through the questions given. Last but not least, the teacher has to remember the concept of FLIP (Table 1).

Table 1. The concept of FLIP

\begin{tabular}{|c|c|c|}
\hline Letters & Acronyms & Meanings \\
\hline $\mathbf{F}$ & $\begin{array}{c}\text { Flexible } \\
\text { Environment }\end{array}$ & $\begin{array}{l}\text { Students can study the } \\
\text { materials in form of } \\
\text { videos anytime and } \\
\text { anywhere. }\end{array}$ \\
\hline $\mathbf{L}$ & $\begin{array}{l}\text { Learning } \\
\text { Culture }\end{array}$ & $\begin{array}{l}\text { This model is a form of } \\
\text { student-centered learning. } \\
\text { So, the students will be } \\
\text { more active in knowledge } \\
\text { construction. }\end{array}$ \\
\hline I & $\begin{array}{c}\text { Intentional } \\
\text { Content }\end{array}$ & $\begin{array}{c}\text { The implementation of } \\
\text { model due to make } \\
\text { students are more engaged } \\
\text { in the learning process and } \\
\text { their cognitive } \\
\text { understanding is } \\
\text { developed. }\end{array}$ \\
\hline $\mathbf{P}$ & $\begin{array}{c}\text { Professional } \\
\text { Teacher }\end{array}$ & $\begin{array}{l}\text { The teacher must be } \\
\text { professional because of his } \\
\text { role in observing the } \\
\text { students, evaluating their } \\
\text { studies, and giving } \\
\text { feedback. }\end{array}$ \\
\hline
\end{tabular}

\subsubsection{Build the assessment system}

The teacher assesses the students. The assessment can be done before teaching, whilst teaching, after teaching. It is based on students' knowledge, and students' practice (performance, project, and portofolio).

3.1.7 Students examine their understandings towards more complicated assignments

In this step, the teacher provides chances for students to answer the questions given. It can be in form of oral or written tests. Based on the students' answers, the teacher is able to know every student's factual, conceptual, procedural, or metacognitive knowledges. Simon [20] says that knowledge has a role in the formation of behavior.

\subsection{Discussion}

The steps of flipped classroom that has been stated are not appropriate for 2013 curriculum. The inappropriate thing is not on the method, but it is on the teaching approaches used, i.e. 1) pedagogical genre, 2) scientific, 3) Content Language Integrated Learning (CLIL). Therefore, the flipped classroom method must be integrated to one of teaching approaches used in 2013 curriculum. The stages of flipped classroom method using scientific approach are shown in Table 2.

The results of research are supported by Nouri [21] who observes students of flipped classroom teaching. They have positive attitude about the video and really increase their motivation, more effective learning, and increased learning. They also tend to agree that flipped classroom makes them 
more active and responsible for their learning. They learn through videos. The learning opportunities are adjusted to their own pace, flexibility. The videos can be accessed easily. Flipped classroom creates more effective learning. Furthermore, research done by Roehl and Linga [22] that in introducing several new teaching models, the teacher must conduct research with alternative models in the classroom. As teacher who will use a new teaching model, it is very important to create effective teaching. In flipped classroom, students develop their creative thinking. Saddhono, Hasanudin, and Fitrianingsih said creative thinking is always needed in everything, especially in solving problems given by the teacher/lecturer [23].

Related to the use of technology, Hasanudin and Fitrianingsih [24] said that flipped classroom and screencasto-matic can be implemented simultaneously. It produces innovative learning syntax and motivates students in learning reading skill. Flipped classroom learning with CyberLink Power Director media apps has already well referred to the negotiation text structure according to the Ministry of Education and Culture [25].

Table 2. The stages of flipped classroom method using scientific approach

\begin{tabular}{|c|c|}
\hline $\begin{array}{c}\text { Flipped } \\
\text { classroom } \\
\text { method } \\
\end{array}$ & $\begin{array}{c}\text { Stages of flipped classroom method } \\
\text { using scientific approach }\end{array}$ \\
\hline The first day & $\begin{array}{l}\text { The teacher of Indonesian language } \\
\text { subject arranges materials based on basic } \\
\text { competence }\end{array}$ \\
\hline $\begin{array}{l}\text { Inform the } \\
\text { students }\end{array}$ & $\begin{array}{l}\text { Teacher asks the students to understand } \\
\text { the concept of flipped classroom }\end{array}$ \\
\hline $\begin{array}{l}\text { Teach how to } \\
\text { access the video }\end{array}$ & $\begin{array}{c}\text { Teacher inform students how to access } \\
\text { the video through YouTube and they } \\
\text { observe the materials }\end{array}$ \\
\hline $\begin{array}{l}\text { Instruct to build } \\
\text { questions }\end{array}$ & $\begin{array}{l}\text { Teacher instruct students to build } \\
\text { questions about unclear materials. They } \\
\text { can prepare themselves to study more or } \\
\text { ask their classmates at home. }\end{array}$ \\
\hline Help each other & $\begin{array}{l}\text { In flipped classroom method, students } \\
\text { have to be able to answer the questions. } \\
\text { Teacher gives chance for them to help } \\
\text { each other to get the answer }\end{array}$ \\
\hline $\begin{array}{l}\text { Build } \\
\text { assessment } \\
\text { system }\end{array}$ & $\begin{array}{l}\text { Teacher assesses every student before } \\
\text { teaching, whilst teaching, and after } \\
\text { teaching based on students' knowledge } \\
\text { and skills. }\end{array}$ \\
\hline $\begin{array}{l}\text { Examine } \\
\text { understandings } \\
\text { towards more } \\
\text { complicated } \\
\text { assignments } \\
\end{array}$ & $\begin{array}{l}\text { Teacher gives chance to answer } \\
\text { questions orally or written. They can } \\
\text { solve the problems given and produce a } \\
\text { new concept related to basic } \\
\text { competence. }\end{array}$ \\
\hline
\end{tabular}

The implementation of flipped classroom gives innovation in the teaching and learning process, the students are motivated to learn the materials in form of videos [26]. Flipped classroom requires technology in form videos [27].

\section{CONCLUSIONS}

Wondershare filmore version 7.8.9 media application can be used in flipped classroom to teach Indonesian language subject. This media contributes to the flipped classroom teaching. In applying flipped classroom teaching on
Indonesian language subject in 2013 curriculum produces a syntax of flipped classroom with scientific approach. This syntax requires students to observe, ask, get information, associate, communicate, and create. Using videos as the teaching materials encourage students to think logically and critically about what they see and hear. There are aspects of this study that limit its generalizability which also provide a focus for future research. We used wondershare filmora version 7.8.9 media apps in flipped classroom teaching.

We suspect that teachers whose much more knowledge about the teaching innovation, in this case, the use of wondershare filmora version 7.8.9 media apps would contribute to create good teaching materials that could be easily accessed by students anywhere and anytime.

\section{ACKNOWLEDGMENT}

This work is supported by LPPM IKIP PGRI Bojonegoro.

\section{REFERENCES}

[1] Sahroji, A., Putra, Y.D. (2018). Sesulit itukah bahasa Indonesia [Is Indonesian language difficult?]. Retrieved from https://www.era.id/read/kGU0RD-sesulit-itukahbahasa-indonesia, accessed on Sept. 17, 2018.

[2] Basuki, B., Suryani, Y.E., Setiadi, D.B.P. (2017). Kesulitan belajar siswa dalam pembelajaran bahasa Indonesia [The students' difficulties in learning Indonesian language]. Litera, 16(1): 12-20. https://doi.org/10.21831/ltr.v16i1.14247

[3] Muslimin. (2011). Perlunya inovasi dalam pembelajaran bahasa dan sastra Indonesia "Solusi mengatasi problem klasik pengajaran bahasa dan sastra di sekolah" [The need of innovation in teaching Indonesian language and literature, the solution to overcome classical problem in teaching language and literature at school]. [The Journal of Language, Literature, and Culture] Jurnal Bahasa, Sastra, dan Budaya, 1(1): 1-8.

[4] Suherli, D.K.K. (2016). Buku guru bahasa Indonesia. Edisi revisi 2016 [The book of Indonesian language teacher. The revision edition of 2016]. Jakarta, Indonesia: Balitbang Kemdikbud.

[5] Permendiknas nomor 22 tahun 2016 tentang Standar Isi untuk Satuan Pendidikan Dasar dan Menengah [The rule of ministry of national education number 22 in 2006 about the standard content for elementery and higher education field].

[6] Basal, A. (2015). Implementation of a flipped classroom in foreign language teaching. Turkish Online Jurnal of Distance Education, 16(4): 28-37. https://doi.org/10.17718/tojde.72185

[7] Herala, A., Vanhala, E., Knutas, A., Ikonen, J. (2015). Teaching programming with flipped classroom method: A study from two programming courses. In Proceedings of the 15th Koli Calling Conference on Computing Education Research. Skinnarilankatu: Lappeeranta University of Technology.

[8] Damayanti, H.N., Sutama, S. (2016). Efektivitas flipped classroom terhadap sikap dan keterampilan belajar matematika Di SMK. Managemen Pendidikan, 11(2): 28. https://doi.org/10.23917/jmp.v11i1.1799

[9] Chandra, F.H. dan Yulius W.N. (2016). Peran teknologi 
video dalam flipped classroom [The role of video technology in flipped classroom]. [Journal of Dynamical Education] Jurnal Dinamika Teknologi, 8(1): 15-20.

[10] Johnson, G.B. (2013). Student Perceptions of the flipped classroom. Columbia: The University of British Columbia.

[11] Hasanudin, C., dan Fitrianingsih, A. (2018). Flipped classroom using screencast-o-matic apps in teaching reading skill in Indonesian language. International Journal of Pedagogy and Teacher Education (IJPTE), 2: 143-150. https://doi.org/10.20961/ijpte.v2i0.25356

[12] Punusingon, R.R., Lumenta, A.S.M., Rindengan, Y.D.Y. (2017). Animasi sosialisasi undang-undang informasi dan transaksi elektronik [The socialization animation of electronics transaction and information rules]. [E-journal of Informational Technique] E-Journal Teknik Informatika, 12(1): 1-8.

[13] Ashshidiqqi, H. (2017). Pengembangan e-book multimedia interaktif berbasis flash pada konsep kingdom animalia [The development of interactive multimedia e-book using flash in the concept of animals] (Skripsi, UIN Syarif Hidayatuullah, Jakarta, Indonesia), retrieved

from http://repository.uinjkt.ac.id/dspace/bitstream/12345678 9/40853/2/HASBI\%20ASHSHIDIQQI-FITK.pdf.

[14] Negara, C.A., Jumrotin, F.N.A. (2017). Pengembangan media pembelajaran bahasa isyarat untuk penyandang cacat rungu wicara berbasis web [The development of sign language web-based teaching media for the deafute people] ([Final report] Laporan Akhir, Politeknik Negeri Malang, Indonesia) retrieved from http://digilib.jti.polinema.ac.id/index.php?p=fstreampdf \&fid $=529 \&$ bid $=1639$.

[15] Sugiyono. (2012). Memahami Penelitian Kualitatif [Understanding Qualitative Research]. Bandung, Indonesia: ALFABETA.

[16] Nurotusholihah, F., Ramdani, S.D. (2017). Pengaruh pemotongan blade terhadap performa low pressure steam turbine [The influence of blade cutting toward the perform of low pressure steam turbine]. VANOS, 2(1): 39-46.

[17] Zed, M. (2008). Metode penelitian kepustakaan [Method of Library Research]. Jakarta, Indonesia: Yayasan Obor Indonesia.

[18] Kuhlthau, C.C. (2002). Teaching the library research process. United States of America: Scarecrow Press, Inc.

[19] Bergmann, J., Sams, A. (2012). Flip your classroom:
Reach every student in every class every day. Washington, DC: Internal Society for Technology in Education.

[20] Retnowati, R., Suharyati, H., Manurung, R.T., Maknun, D., Armariena, D.N., Hetilaniar, H., Hasanudin, C., Murniviyanti, L., Anwar, S., Setyorini, R. (2018). The effect of environmental teaching method and the level of natural intelligence on the environmental view of the students behavior. Journal of Physics: Conference Series, 1114(1): https://doi.org/10.1088/17426596/1114/1/012104

[21] Nouri, J. (2016). The flipped classroom: For active, effective and increased learning-especially for low achievers. International Journal of Educational Technology in Higher Education, 13(1): 33.

[22] Roehl, A., Linga, S. (2013). The flipped classroom: An opportunity to engage millennial students through active learning strategies. Christian University Jurnal Internasional, 105(2): 44-49.

[23] Saddhono, K., Hasanudin, C., Fitrianingsih, A. (2019). The ability to think creatively on SSCS using schoology Apps, how is the student's language metacognitive awareness? Ingénierie des Systèmes d'Information, 24(4): 367-375. https://doi.org/10.18280/isi.240402

[24] Hasanudin, C., dan Fitrianingsih, A. (2018). The implementation of flipped classroom using screencast-omatic to improve students' verbal linguistic intelligence. International Journal of Engineering \& Technology, 7(4) 435-439. https://doi.org/10.14419/ijet.v7i4.15.23602.

[25] Hasanudin, C., Fitrianingsih, A., Saddhono, K. (2019). How is the student's negotiation text in collaborative learning of flipped classroom and a CyberLink power director media apps. Ingénierie des Systèmes d'Information, 24(6): 559-567. https://doi.org/10.18280/isi.240601

[26] Hasanudin, C., Fitrianigsih, A. (2019). Analisis gaya belajar mahasiswa pada pembelajaran flipped classroom [The Analysis of Student's Learning Style in Flipped Classroom Teaching]. [The Journal of Edutama Education] Jurnal Pendidikan Edutama, 6(1): 31-36. https://doi.org/10.30734/jpe.v6i1.364

[27] Hasanudin, C., Fitrianingsih, A. (2018). The implementation of flipped classroom using screencastomatic to improve students' verbal linguistic intelligence. International Journal of Engineering \& Technology, 7(4.15): 435-439. https://doi.org/10.14419/ijet.v7i4.15.23602 